\title{
STUDI KOMPARASI PENGGUNAAN ICE BREAKING DAN BRAIN GYM TERHADAP MINAT BELAJAR MATEMATIKA SISWA KELAS VII SMP NEGERI 21 MAKASSAR
}

\author{
Fatwal Harsyad1), Ahmad Afif'), Andi Ika Prasasti Abrar'3) \\ 1,2,3Fakultas Tarbiyah dan Keguruan UIN Alauddin Makassar \\ 1,2,3Kampus II: Jalan H. M. Yasin Limpo Nomor 36 Samata-Gowa \\ E-mail: fatwalharsyad@yahoo.com ${ }^{1)}$, ahmadafif@ymail.com²), \\ asty_math03@yahoo.co.id ${ }^{3)}$
}

\begin{abstract}
Abstrak:
Penelitian ini bertujuan untuk mengetahui perbandingan minat belajar matematika siswa Kelas VII SMP Negeri 21 Makassar yang diajar menggunakan Ice Breaking dan Brain Gym dalam pembelajaran matematika. Penelitian ini merupakan jenis penelitian quasi experimental design dengan desain penelitian comparison group post-test only design. Populasi dalam penelitian ini adalah seluruh siswa kelas VII SMP Negeri 21 Makassar yang berjumlah 356 siswa. Penentuan sampel menggunakan teknik simple random sampling. Berdasarkan hasil analisis deskriptif diperoleh rata-rata skor minat belajar dari kelas Eksperimen I yang diajar menggunakan Ice Breaking adalah 77,13 dan rata-rata skor minat belajar dari kelas Eksperimen II yang diajar menggunakan Brain Gym adalah 77,43. Sedangkan berdasarkan hasil analisis inferensial diperoleh nilai sig. sebesar 0,904 yang lebih besar dari pada $\alpha$ sebesar $0,05(0,904>0,05)$ dengan demikian dapat disimpulkan bahwa $\mathrm{H}_{0}$ diterima yang berarti bahwa tidak terdapat perbedaan minat belajar matematika siswa yang diajar menggunakan Ice Breaking dengan yang diajar menggunakan Brain Gym pada siswa kelas VII SMP Negeri 21 Makassar. Implikasi pada penelitian ini adalah pembelajaran matematika menggunakan Ice Breaking maupun Brain Gym sesuai untuk diterapkan dalam pembelajaran matematika karena sama-sama dapat menciptakan pembelajaran yang kreatif agar siswa tidak merasa bosan dalam mengikuti pembelajaran matematika. Suasana belajar menyenangkan tersebut dapat membuat minat belajar peserta didik meningkat.
\end{abstract}

Kata Kunci: Minat Belajar, Ice Breaking, Brain Gym

$\mathrm{P}$ endidikan nasional pada hakikatnya diarahkan pada pembangunan Indonesia seutuhnya yang menyeluruh baik lahir maupun batin. Pendidikan yang berkualitas akan menghasilkan sumber daya manusia yang berkualitas pula. Berdasarkan Undang-undang Nomor 20 Tahun 2003 tentang sistem pendidikan nasional pada hakikatnya pendidikan nasional berfungsi mengembangkan kemampuan dan membentuk watak serta 
peradaban bangsa yang bermartabat dalam rangka mencerdaskan kehidupan bangsa.

Sehubungan dengan hal tersebut, pembangunan di bidang pendidikan merupakan wahana yang sangat baik dalam pembinaan sumber daya manusia Indonesia. Realisasi dari pelaksanaan pembangunan di bidang pendidikan salah satunya dengan pendidikan formal di sekolah yang dilaksanakan secara berjenjang dan berkesinambungan. Dimulai dari jenjang pendidikan dasar sampai perguruan tinggi dimana tiap jenjang pendidikan mempunyai peranan masing-masing.

Menurut Bunda (2016:40) Kegiatan pembelajaran di kelas merupakan jantung kurikulum berhasil atau tidaknya pencapaian tujuan pendidikan. Dengan demikian, guru sebagai pembimbing siswa dalam belajar di kelas harus mampu mengelola proses pembelajaran agar efektif. Keberhasilan dari proses belajar di kelas ditandai dengan tercapainya tujuan pengajaran serta prestasi belajar yang optimal.

Proses pembelajaran yang efektif terdiri atas kegiatan pendahuluan, kegiatan inti dan kegiatan penutup. Tahap pendahuluan atau tahap persiapan berkaitan dengan mempersiapkan peserta didik untuk belajar. Hal ini berarti bahwa untuk memulai proses belajar, peserta didik harus siap dan mau untuk belajar. Menurut Mahmud (2012:99) Peserta didik tidak berada dalam tekanan, tetapi dalam keadaan senang, gembira dan tertarik untuk memulai pelajaran. Dengan kata lain diperlukan minat belajar yang tinggi pada peserta didik untuk memulai proses pembelajaran. Menurut Aritonang (2008:14) Seorang guru harus mampu membangkitkan minat belajar peserta didik terhadap pelajaran yang diajarkannya. Terutama untuk mata pelajaran sains yang biasanya memiliki tingkat minat belajar peserta didik yang rendah. Salah satu mata pelajaran sains yang pada umumnya kurang diminati siswa adalah mata pelajaran matematika.

Kondisi ini juga yang terjadi pada pembelajaran matematika di SMP Negeri 21 Makassar. Berdasarkan hasil wawancara pada tanggal 7 september 2015 dengan Ibu Hj. Hanurung sebagai guru mata pelajaran matematika SMP Negeri 21 Makassar, diketahui bahwa minat siswa terhadap mata pelajaran matematika tergolong masih rendah. Hal ini ditandai dengan banyaknya siswa yang tidak menunjukkan rasa senang dan perhatian pada saat mata pelajaran matematika berlangsung, tidak konsentrasi, dan kurangnya keterlibatan siswa. Untuk mengetahui penyebabnya, penulis juga mencoba mewawancarai beberapa siswa SMP Negeri 21 Makassar yakni Nur Alvia, 
Rosnita dan Raihan Alfiansyah. Hasil wawancara tersebut menghasilkan kesimpulan bahwa salah satu penyebab rendahnya minat belajar siswa pada mata pelajaran matematika adalah proses pembelajaran matematika yang membosankan, monoton, dan begitu-begitu saja tanpa adanya inovasi lain, sehingga pembelajaran terasa kurang menyenangkan bagi siswa.

Menurut Aritonang (2008: 18-21) Salah satu metode untuk meningkatkan minat belajar peserta didik adalah melalui apersepsi pada tahap pendahuluan pembelajaran. Apersepsi adalah stimulus khusus pada awal belajar yang bertujuan meraih perhatian dari para peserta didik. Jadi apersepsi itu membangkitkan minat dan perhatian untuk sesuatu. Apersepsi juga dimaknai sebagai menciptakan kondisi zona alfa pada otak, yaitu kondisi terbaik untuk belajar bagi peserta didik sebab pada kondisi alfa, neuron berada dalam suatu harmoni atau keseimbangan.

Menurut Dunlap (2013:3) menyatakan bahwa Ice Breaking berupa permainan adalah salah satu cara yang efektif dalam pembelajaran. Penelitian yang dilakukan oleh Riya Susanah dan Dedi Hidayatullah Alarifin menunjukkan hasil yang positif bahwa kegiatan pembelajaran fisika dengan menerapkan Ice Breaking dapat membuat suasana kelas menjadi lebih menyenangkan sehingga motivasi siswa untuk belajar fisika meningkat dan berpengaruh pada hasil belajar fisika yang juga meningkat.

Selain Ice Breaking, terdapat juga Brain Gym. Menurut Andre (2012) Brain Gym adalah serangkaian latihan gerak yang sederhana dan menyenangkan untuk memudahkan kegiatan belajar dan penyesuaian dengan tuntutan sehari-hari. Menurut karluki (2014:10) Adanya hubungan yang positif antara penggunaan Brain Gym dengan minat belajar siswa setidaknya telah dibuktikan melalui penelitian yang dilakukan oleh Fitri Handayani. Penelitian ini menunjukkan bahwa penggunaan metode Brain Gym dalam pembelajaran matematika dapat meningkatkan konsentrasi dan minat belajar peserta didik. Senada dengan hasil penelitian tersebut, penelitian oleh Yudi Andrejuga menyatakan bahwa pembelajaran dengan Brain Gym lebih efektif terhadap minat belajar siswa jika dibandingkan dengan proses pembelajaran konvensional. Hal ini ditandai dengan adanya perbedaan signifikan antara minat belajar siswa yang diajar menggunakan Brain Gym dengan proses pembelajaran konvensional.

Berdasarkan hal tersebut, penulis tertarik untuk mencoba membandingkan penggunaan kedua metode tersebut dengan objek siswa kelas VII SMP Negeri 21Makassar dengan pertimbangan minat belajar siswa 
yang rendah melalui penelitian dengan judul "Studi Komparasi Penggunaan Ice Breaking dan Brain Gym Terhadap Minat Belajar Matematika Siswa Kelas VII SMP Negeri 21 Makassar".

\section{MINAT BELAJAR}

Menurut Utami (2014:9) Minat dapat diartikan sebagai suatu yang menjadi sumber identifikasi anak dengan keberadaan pribadinya. Minat merupakan sumber motivasi yang mendorong seseorang untuk melakukan sesuatu yang diinginkannya. Hal ini berarti minat dapat timbul ketika seseorang tahu apa manfaat yang akan diperoleh setelah melakukan sesuatu. Dapat dikatakan seseorang akan tumbuh minat untuk belajar ketika dia tahu apa manfaat yang akan diperolehnya setelah melakukan proses belajar tersebut.

Minat merupakan suatu sifat yang relatif menetap pada diri seseorang. Minat besar sekali pengaruhnya terhadap belajar sebab dengan minat seseorang akan melakukan sesuatu yang diminatinya. Jadi minat belajar adalah kecenderungan dan ketertarikan yang mendorong seseorang untuk mau melakukan proses belajar dengan kesadaran dan kemauan sendiri tanpa ada yang menyuruh. Minat belajar memiliki peran penting untuk mendukung keberhasilan belajar seseorang.

Menurut Wasti (2013) Minat belajar seseorang dapat dilihat dari berbagai indikator minat belajar yang menunjukkan seberapa besar minat seseorang dalam suatu pembelajaran tertentu. Menurut Safari dalam Wasti, aspek minat belajar yaitu perasaan senang, ketertarikan siswa, perhatian dan keterlibatan siswa.

Menurut Yang (2016:18) Pentingnya minat belajar pada peserta didik mendasari tujuan umum para pendidik terutama pendidik pada bidang pelajaran sains untuk membantu peserta didik mengembangkan minat belajar pada pelajaran sains karena minat belajar dapat meningkatkan kualitas pembelajaran

\section{ICE BREAKING}

Istilah ice breaker berasal dari dua kata asing, yaitu ice yang berarti es yang memiliki sifat kaku, dingin, dan keras, sedangkan breaker berarti memecahkan. Arti harfiah ice-breaker adalah "pemecah es". Jadi, ice breaker bisa diartikan sebagai usaha untuk memecahan atau mencairkan suasana yang kaku seperti es agar menjadi lebih nyaman mengalir dan santai. Menururt 
Chatib (2015: 99-100) Ice Breaking merupakan sentuhan aktivitas yang dapat digunakan untuk memecahkan kebekuan, kekalutan, kejemuan dan kejenuhan suasana sehingga menjadi mencair dan suasana bisa kembali pada keadaan semula (lebih kondusif). Jika sentuhan aktivitas ini diterapkan pada proses pembelajaran dikelas, maka besar kemungkinannya siswa kembali pada kondisi (semangat, motivasi, gairah belajar, dan lain sebagainya) yang lebih baik. Suasana kondusif tersebut akan lebih efektif untuk membantu siswa mencapai tujuan pembelajaran dibandingkan dengan suasana yang tegang.

Menurut Dunlap (2013:3) Permainan penyegaran (Ice Breaking) adalah suatu kegiatan yang dilakukan untuk mencairkan suasana pembelajaran yang membosankan, kaku, dan pasif menjadi kegiatan pembelajaran yang menyenangkan, menyegarkan, aktif dan membangkitkan motivasi untuk belajar lebih bergairah. Dengan kata lain Ice Breaking juga berfungsi untuk meningkatkan minat belajar peserta didik karena minat belajar adalah kondisi dimana siswa merasa bergairah untuk melakukan proses belajar.

Menurut Fanani (2010: 69) Ada beberapa manfaat melakukan aktivitas Ice Breaking, diantaranya adalah menghilangkan kebosanan, kejemuan, kecemasan, dan keletihan karena bisa keluar sementara dari rutinitas pelajaran dengan melakukan aktivitas gerak bebas dan ceria, juga manfaat lain seperti : (1) Melatih berpikir secara kreatif dan luas siswa, (2) mengembangkan dan mengoptimalkan otak dan kreativitas siswa, (3) melatih siswa berinteraksi dalam kelompok dan bekerjasama dalam satu tim, (4) melatih berpikir sistematis dan kreatif untuk memecahkan masalah, (5) meningkatkan rasa percaya diri, (6) melatih menentukan strategi secara matang, (7) Melatih kreativitas dengan bahan yang terbatas, (8) melatih konsentrasi, berani bertindak dan tidak takut salah, (9) merekatkan hubungan interpersonal yang renggang, (10) melatih untuk menghargai orang lain, (11) memantapkan konsep diri, (12) melatih jiwa kepemimpinan, (13) melatih bersikap ilmiah, (14) melatih mengambil keputusan dan tindakan. Berdasarkan beberapa manfaat tersebut, maka jelaslah bahwa ice breaking dapat menjadi salah satu alternatif untuk digunakan dalam pembelajaran agar pembelajaran tidak monoton dan tidak membosankan bagi siswa. Terutama sangat baik digunakan dalam proses pembelajaran matematika yang biasanya terkesan menegangkan dan menakutkan bagi siswa

Menurut Chatib (2014:100 ), Syarat-syarat Ice Breaking di dalam kelas yang berfungsi mengembalikan siswakembali ke zona alfa adalah: 1. Ice Breaking dilakukan dalam waktu singkat, makin singkat makin baik. 
2. Ice Breaking diikuti seluruh siswa.

3. Guru dapat menjelaskan dengan singkat teaching-point atau maksud Ice Breaking dalam waktu tidak terlalu lama agar siswa dapat mengetahui apa manfaat melakukan aktifitas tersebut.

4. Apabila target sudah terpenuhi, yaitu siswa sudah kembali senang, segera kembali ke materi pelajaran.

\section{BRAIN GYM}

Menurut Dennison (2009: 6) Senam otak atau Brain Gym adalah serangkaian latihan berbasis gerakan tubuh sederhana. Gerakan ini dibuat untuk merangsang otak kiri dan kanan (dimensi lateralitas), meringankan atau merelaksasi bagian belakang dan bagian depan otak (dimensi kerja atau fokus perhatian), serta merangsang sistemyang terkait dengan perasaan atau emosional, yakni otak tengah (limbis) serta otak besar (dimensi pemusatan). Berdasarkan definisi ini senam otak terdiri atas serangkaian gerakan untuk merangsang otak kiri, otak kanan dan otak tengah. Selama ini orang di dunia ternyata hanya mengandalkan otak kiri saja padahal otak dapat dioptimalkan fungsinya dengan menyeimbangkan ketiga bagian otak tersebut.

Menurut handayani (2010) senam otak (brain gym) adalah suatu usaha untuk membangkitkan fungsi-fungsi neuron dalam mengkoordinasikan gerakan tubuh. Pada senam otak ini dilakukan gerakan-gerakan yang membutuhkan koordinasi antara otak kanan dan otak kiri. Semakin sering kita melakukan senam otak ini, semakin banyak koneksi neuron pada otak.

Menurut Haryanto (2011:7) Kekuatan yang dimiliki oleh gerakangerakan sederhana brain gym mengaktifkan kembali fungsi seluruh otak melalui hubungan yang intim dengan gerakan-gerakan tubuh. Brain gym terdiri dari gerakan-gerakan terintegrasi kontralateral yang menuntut keseimbangan, yang secara mekanis mengaktifkan kedua hemisfer otak melalui korteks motorik dan korteks sensoris, merangsang vestibular untuk mencari keseimbangan dan mengurangi mekanisme "melawan atau lari". Dalam keadaan seimbang ini, lebih mudah bagi kita untuk berpikir, memahami, dan muncul dengan ide-ide dan solusi-solusi baru.

Menurut Sunarto (2012) anak-anak maupun orang dewasa menggunakan brain gym untuk membantu mengintegrasikan tubuh dan pikiran dengan mengembangkan otak melalui gerakan. Sehingga dikatakan pembelajaran dengan keseluruhan otak. Menurut Susanah (2014: 50) Brain gym bermanfaat untuk meningkatkan: (1) Konsentrasi dan fokus, (2) Ingatan, (3) 
Kemampuan membaca, (4) Kemampuan menulis, (5) Kemampuan mengatur (organizing), (6) Kemampuan mendengar, (7) Koordinasi fisik, (8) Kemampuan menyelesaiakan rencana, (9) Kemampuan belajar, (10) Performa olahraga.

Berdasarkan uraian tersebut maka brain gym memiliki banyak sekali manfaat salah satunya dalam proses belajar misalnya sebagai apersepsi. Brain gym juga biasanya digunakan sebagai cara untuk membawa kembali peserta didik kembali ke zona alfa dalam proses pembelajaran.

\section{METODE PENELITIAN}

Pendekatan dalam penelitian ini adalah pendekatan kuantitatif. Jenis penelitian yang digunakan adalah penelitian quasi experimental design. Desain ini mempunyai kelompok kontrol tetapi tidak berfungsi sepenuhnya untuk mengontrol variabel-variabel luar yang mempengaruhi pelaksanaan eksperimen. Model desain pada penelitian kali ini menggunakan desain penelitian oleh Richard M. Grinnel,Peter A. Gabor dan Yvonne A. Unrau yakni comparison group post-test only design. Kelas Eksperimen I adalah proses pembelajaran matematika menggunakan ice breaking dan perlakuan untuk Kelas Eksperimen II adalah proses pembelajaran matematika menggunakan brain gym. Lokasi penelitian bertempat di SMP Negeri 21 Makassar, Kelurahan Karunrung, Kecamatan Rappocini, KotaMakassar, Provinsi Sulawesi Selatan.

Populasi dalam penelitian ini adalah seluruh peserta didik kelas VII SMP Negeri 21 Makassar yang berjumlah 356 peserta didik yang terdiri atas dua belas kelas dari kelasVIIA sampai VIIL. Sampel untuk penelitian ini terdiri atas satu Kelas Eksperimen I yaitu kelas VIIE dan satu Kelas Eksperimen II yaitu kelas VIIH.

Adapun instrumen dalam penelitian ini adalah skala minat belajar dan lembar observasi. Teknik analisis data yang digunakan dalam penelitian ini adalah analisis statistik, dimana ada tiga variabel yang akan diuji yaitu pembelajaran matematika menggunakan Ice Breaking (variable $\mathrm{X}_{1}$ ), pembelajaran matematika menggunakan Brain Gym (variabel $\mathrm{X}_{2}$ ) dan minat belajar matematika peserta didik (variabel Y). Berdasarkan rumusan masalah yang diuraikan sebelumnya maka pengolahan data hasil penelitian menggunakan analisis statistik deskriptif dan analisis statistik inferensial. Analisis statistik deskriptif digunakan untuk mendeskripsikan data hasil penelitian masing-masing variabel secara tunggal, dalam hal ini meliputi ratarata, standar deviasi, presentasi dan tabel frekuensi. Statistik inferensial 
adalah teknik analisis data yang digunakan untuk menganalisis data sampel dan hasilnya diberlakukan untuk populasi. Statistik inferensial digunakan untuk menguji hipotesis penelitian yang diajukan. Sebelum melakukan pengujian hipotesis, dilakukan uji prasyarat yaitu uji normalitas dan uji homogenitas.

\section{HASIL PENELITIAN DAN PEMBAHASAN}

Deskripsi Minat Belajar Matematika Peserta Didik Kelas VII SMPN 21 Makassar yang diajar Menggunakan Ice Breaking dalam Pembelajaran Matematika (X1)

Berdasarkan data observasi pelaksanaan kegiatan pembelajaran matematika menggunakan Ice Breaking pada kelas eksperimen I, diperoleh hasil sebagai berikut:

Tabel 1. Data Pelaksanaan Pembelajaran Matematika Menggunakan Ice Breaking

\begin{tabular}{ccccc}
\hline No & Pengamatan & Jumlah Skor & Rata-Rata & Ket. \\
\hline 1 & Aktivitas Guru & 36 & 3,6 & Sangat Baik \\
2 & Aktivitas Peserta Didik & 35 & 3,5 & Sangat Baik \\
\hline \multicolumn{7}{r}{ Rata-rata Total } & & 3,55 & Sangat Baik \\
\hline
\end{tabular}

Tabel tersebut menunjukkan bahwa skor aktivitas guru pada pelaksanaan kegiatan pembelajaran matematika menggunakan Ice Breaking berjumlah 36 dengan rata-rata 3,6 sehingga memenuhi kategori pelaksanaan sangat baik. Sedangkan skor aktivitas peserta didik pada pelaksanaan kegiatan pembelajaran matematika menggunakan Ice Breaking berjumlah 35 dengan rata-rata 3,5 sehingga memenuhi kategori pelaksanaan sangat baik. Rata-rata total dari aktivitas guru dan aktivitas peserta didik pada pelaksanaan kegiatan pembelajaran matematika menggunakan Ice Breaking adalah 3,55 maka dapat disimpulkan bahwa kegiatan pembelajaran matematika menggunakan Ice Breaking dilaksanakan dengan sangat baik. 
Tabel 2. Descriptive Statistics Minat Belajar Matematika Peserta Didik Kelas VII SMPN 21 Makassar yang diajar Menggunakan Ice Breaking dalam Pembelajaran Matematika

\begin{tabular}{cc}
\hline Statistik & Nilai Kelas Eksperimen 1 \\
\hline Jumlah Sampel & 30 \\
Nilai Terendah & 60 \\
Nilai Tertinggi & 96 \\
Nilai Rata-rata & 77,13 \\
Standar Deviasi & 7,999 \\
\hline
\end{tabular}

Deskripsi Minat Belajar Matematika Peserta Didik Kelas VII SMPN 21 Makassar yang Diajar Menggunakan Brain Gym dalam Pembelajaran Matematika $\left(X_{2}\right)$

Berdasarkan data observasi pelaksanaan kegiatan pembelajaran matematika menggunakan Brain Gym pada kelas eksperimen II, diperoleh hasil sebagai berikut:

Tabel 3. Data Pelaksanaan Pembelajaran Matematika Menggunakan Brain Gym

\begin{tabular}{ccccc}
\hline No & Pengamatan & Jumlah Skor & Rata-Rata & Ket. \\
\hline 1 & Aktivitas Guru & 37 & 3,7 & Sangat Baik \\
2 & Aktivitas Peserta Didik & 36 & 3,6 & Sangat Baik \\
\hline & Rata-rata Total & & 3,65 & Sangat Baik \\
\hline
\end{tabular}

Tabel tersebut menunjukkan bahwa skor aktivitas guru pada pelaksanaan kegiatan pembelajaran matematika menggunakan Brain Gym berjumlah 37 dengan rata-rata 3,7 sehingga memenuhi kategori pelaksanaan sangat baik. Sedangkan skor aktivitas peserta didik pada pelaksanaan kegiatan pembelajaran matematika menggunakan Brain Gym berjumlah 36 dengan rata-rata 3,6 sehingga memenuhi kategori pelaksanaan sangat baik. Rata-rata total dari aktivitas guru dan aktivitas peserta didik pada pelaksanaan kegiatan pembelajaran matematika menggunakan Brain Gym adalah 3,65 maka dapat disimpulkan bahwa kegiatan pembelajaran matematika menggunakan Brain Gym dilaksanakan dengan sangat baik.

Selanjutnya berdasarkan hasil penelitian yang dilaksanakan di SMPN 21 Makassar dan angket yang diberikan pada peserta didik pada kelas Eksperimen II sesudah penggunaan Brain Gym di kelas VII SMPN 21 
Makassar yang telah diolah dengan SPSS 20,0 didapatkan hasil sebagai berikut:

Tabel 4. Descriptive Statistics Minat Belajar Matematika Peserta Didik Kelas VII SMPN 21 Makassar yang diajar Menggunakan Brain Gym dalam Pembelajaran Matematika

\begin{tabular}{cc}
\hline Statistik & Nilai Kelas Eksperimen II \\
\hline Jumlah Sampel & 30 \\
Nilai Terendah & 45 \\
Nilai Tertinggi & 96 \\
Nilai Rata-rata & 77,43 \\
Standar Deviasi & 10,881 \\
\hline
\end{tabular}

Perbandingan minat belajar matematika siswa Kelas VII SMP Negeri 21 Makassar yang diajar menggunakan Ice Breaking dengan yang diajar menggunakan Brain Gym

Berikut diagram batang yang menggambarkan perbandingan minat belajar kelas Eksperimen I dan kelas Eksperimen II adalah sebagai berilkut :

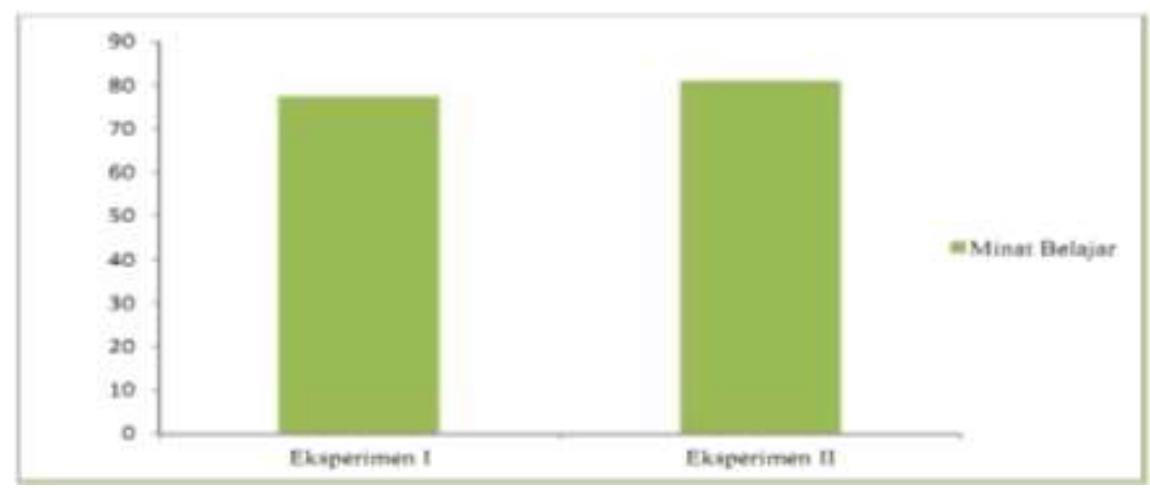

Gambar 1. Diagram Perbandingan Rata-rata Minat Belajar Matematika Kelompok Eksperimen I dan Kelompok Eksperimen II

Selanjutnya akan dilakukan analisis statistik inferensial untuk mengetahui apakah ada perbedaan yang signifikan terhadap penerapan Ice Breaking dan Brain Gym terhadap minat belajar matematika siswa kelas VII SMPN 21 Makassar atau tidak. Penulis melakukan analisis dengan melihat data minat belajar setelah diterapkan kedua teknik tersebut yang diperoleh pada kelas Eksperimen I ( $\left.\mathrm{X}_{1}\right)$ dan kelas Eksperimen II $\left(\mathrm{X}_{2}\right)$. 
Taraf signifinikan yang ditetapkan adalah $\alpha=0,05$. Berdasarkan hasil pengolahan dengan SPSS 20.0 maka diperoleh sig. untuk kelas Eksperimen I (Ice Breaking) adalah 0,789 dan sig. untuk kelas Eksperimen II (Brain Gym) adalah 0,872 dengan demikian dapat disimpulkan bahwa data minat belajar kelas Eksperimen I dan kelas Eksperimen II berdistribusi normal karena nilai sig. untuk kedua kelas tersebut lebih besar dari a $(0,789>0,05$ dan $0,872>0,05)$. Uji homogenitas bertujuan untuk melihat apakah data pada kedua kelompok memiliki variansi yang sama (homogen) atau tidak. Berdasarkan hasil uji homogenitas data minat belajar, diperoleh nilai $\mathrm{F}$ hitung =1,497 dan nilai Sig. =0,226. Tampak bahwa nilai probabilitas (nilai Sig.) lebih besardari 0,05 $(0,226>0,05)$ maka dapat disimpulkan bahwa data pada kedua kelompok memiliki variansi yang sama (homogen)

Teknik pengujian yang digunakan adalah uji independent sample t-test dengan taraf signifikan $a=0,05$. Berdasarkan hasil perhitungan menggunakan SPSS 20,0 diperoleh nilai $t_{\text {hitung }}=-0,122$ dan nilai sig. $=0,904$ sehingga dapat disimpulkan bahwa $\mathrm{H}_{0}$ diterima dan $\mathrm{H}_{1}$ ditolak karena nilai sig. $>a(0,904>0,05)$. Maka tidak terdapat perbedaan antara minat belajar matematika siswa kelas VII SMPN 21 Makassar dengan penerapan Ice Breaking dan Brain Gym.

Minat belajar kelas Eksperimen I yang melaksanakan kegiatan pembelajaran matematika dengan menggunakan Ice Breaking dapat digolongkan pada kategori tinggi. Hal ini dapat dibuktikan dengan tidak ada peserta didik atau $0 \%$ yang memiliki minat yang rendah, 6 peserta didik atau 20\% yang memiliki minat yang sedang, dan 24 peserta didik atau $80 \%$ yang memiliki minat yang tinggi. Sedangkan minat belajar kelas Eksperimen II yang melaksanakan kegiatan pembelajaran matematika dengan menggunakan Brain Gym juga dapat digolongkanpada kategori tinggi, hal ini dapat dibuktikan dengan 1 peserta didik atau 3\% yang memiliki minat yang rendah, 6 peserta didik atau 20\% yang memiliki minat yang sedang, dan 23 peserta didik atau 77\% yang memiliki minat yang tinggi.

Berdasarkan data yang ada, pada kelas Eksperimen I diketahui bahwa rata-rata skor minat belajar matematika peserta didik adalah 77,13 dan pada kelas Eksperimen II rata-rata skor minat belajar matematika peserta didik adalah 77,43. Hal ini membuktikan bahwa tidak ada perbedaan yang signifikan antara minat belajar matematika peserta didik pada kelas Eksperimen I dan kelas Eksperimen II. 
Tidak adanya perbedaan minat belajar siswa diakibatkan oleh beberapa faktor. Salah satunya adalah langkah-langkah pembelajaran yang hampir sama. Ice Breaking dan Brain Gym sama-sama merupakan yang digunakan dalam proses pembelajaran dan keduanya dapat meningkatkan minat belajar peserta didik.

\section{SIMPULAN}

Berdasarkan hasil penelitian dan pembahasan sebelumnya, maka diperoleh beberapa kesimpulan sebagai berikut:

a. Minat belajar matematika siswa kelas VII SMPN 21 Makassar yang diajar menggunakan Ice Breaking dalam pembelajaran pada kelas eksperimen I berada pada kategori tinggi dengan presentase $80 \%$ dari seluruh jumlah siswa di kelas VIIE.

b. Minat belajar matematika siswa kelas VII SMPN 21 Makassar yang diajar menggunakan Brain Gym dalam pembelajaran kelas eksperimen II berada pada kategori tinggi dengan presentase $77 \%$ dari seluruh jumlah siswa di kelas VIIH.

c. Setelah melakukan penelitian, maka dapat dikatakan bahwa tidak ada perbedaan rata-rata yang signifikan antara skor minat belajar matematika siswa kelas VIIE SMPN 21 Makassar yang diajar menggunakan Ice Breaking dalam pembelajaran dengan skor minat belajar matematika siswa kelas VIIH SMPN 21 Makassar yang diajar menggunakan Brain Gym dalam pembelajaran. Minat belajar matematika yang menggunakan Ice Breaking dalam pembelajaran sama baiknya jika dibandingkan dengan menggunakan Brain Gym dalam pembelajaran. Hal ini dapat dilihat pada rata-rata skor minat belajar pada kelas Eksperimen I $($ Ice Breaking $)=77,13$ dan kelas Eksperimen II (Brain Gym) $=77,43$. Cara mengetahui adanya perbedaan yang signifikan atau tidak antara hasil belajar siswa kelas eksperimen I dan kelas eksperimen II yaitu dengan menggunakan uji independent sample $t$-test sebagai uji hipotesis. Hasil analisis menunjukkan bahwa nilai signifikansi yaitu 0,904. Sehingga nilai sig $>0,05(0,904>$ 0,05). Hal ini dapat diartikan bahwa minat belajar matematika peserta didik pada kedua kelas berada pada kategori tinggi namun tidak terdapat perbedaan minat belajar matematika peserta didik yang signifikan antara keduanya. 


\section{DAFTAR PUSTAKA}

Andre, Y. (2012). Efektivitas penggunaan metode brain gym terhadap minat belajar IPA siswa kelas V SD Negeri Kalibeji Kecamatan Tuntang Kabupaten Semarang semester II tahun pelajaran 2011/2012. Skripsi. Fakultas Keguruan dan Ilmu Pendidikan Universitas Kristen Satya Wacana, Salatiga.

Aritonang, K. (2008). Minat dan motivasi dalam meningkatkan hasil belajar siswa. Jurnal Pendidikan Penabur, 7(10).

Chatib, M. (2014). Gurunya manusia: Menjadikan semua anak istimewa dan semuaanak juara. Bandung: Mizan.

Dennison, P. E., \& Gail, E. D. (2009). Brain Gym Children's Edition Revised: Senam Otak Buku Panduan Lengkap. Jakarta: Grasindo.

Dunlap, D. (2013). Games and icebreakers for the ESL classroom. English LanguangeFellow Mauritania.

Fanani, A. (2010). Ice breaking dalam proses belajar mengajar. Jurnal Pendidikan, 6(11).

Handayani, F. (2010). Optimalisasi penggunaan metode brain gym dalam pembelajaran matematika untuk meningkatkan konsentrasi dan minat belajar siswa MTS Muh Waru kelas VIII. Skripsi, Fakultas Keguruan dan IlmuPendidikan Unismuh, Surakarta.

Haryanto, B. K. (2011). Peningkatan minat belajar matematika siswa melalui penerapan brain gym dan pendekatan kooperatif student team achievement division. Skripsi, Fakultas Keguruan dan Ilmu Pendidikan Universitas Muhammadiyah Surakarta.

Karluki, P. N. \& Holly D. K. (2014). The effect of brain gym activities and traditional teaching strategies on student's performance in comprehension in a 4th grade classroom. Mid-South Educational Research Association.

Lucy, Bunda. (2016). Panduan praktis tes minat $\mathcal{E}$ bakat anak. Jakarta: Penebar Swadaya.

Mahmud. (2012). Psikologi pendidikan. Bandung: Pustaka Setia.

Sunarto. (2012). Ice breaker dalam pembelajaran aktif. Surakarta: Yuma Pustaka. 
Susanah, R. \& Alarifin, D. H. (2014). Penerapan permainan penyegar (ice breaking) dalam pembelajaran fisika untuk meningkatkan motivasi dan hasil belajar. Jurnal Pendidikan Fisika, 2(1).

Utami, T. (2014). Penggunaan media lagu (nyanyian) untuk meningkatkan minat belajar siswa pada mata pelajaran IPA kelas IV SD Negeri Tlogopandogan 2. Skripsi. Fakultas Keguruan dan Ilmu Pendidikan UniversitasMuhammadiyah Surakarta.

Wasti, S. (2013). Hubungan minat belajar dengan hasil belajar mata pelajaran tata busana di Madrasah Aliyah Negeri 2 Padang. Journal Home Economic and Tourism, 2(1).

Yang, L. (2016). Interpersonal relationships and the development of studentinterest in science. Electronic Journal of Science Education South western University, 20(1). 